Revista Eletrônica de Direito Processual - REDP. Volume 16. Julho a dezembro de 2015

Periódico Semestral da Pós-Graduação Stricto Sensu em Direito Processual da UERJ

Patrono: José Carlos Barbosa Moreira. ISSN 1982-7636. pp. 211-239 http://www.e-publicacoes.uerj.br/index.php/redp/index

\title{
INCIDENTE DE RESOLUÇÃO DE DEMANDAS REPETITIVAS: PROJEÇÕES EM TORNO DE SUA EFICIÊNCIA ${ }^{1}$
}

\section{INCIDENT OF SETTLEMENT OF REPETITIOUS CLAIMS: PROJECTIONS AROUND THE EFFICIENCY THEREOF}

Guilherme Puchalski Teixeira Mestre e Doutorando em Direito pela PUCRS. Professor de Direito Processual Civil e Direito Empresarial. Advogado. guilherme@tt.adv.br

RESUMO: O cenário atual é de visível incompatibilidade entre a litigiosidade e a capacidade do Poder Judiciário em absorver tal demanda. Ao conhecido problema da morosidade somase a dificuldade da falta de previsibilidade da jurisdição na solução de demandas sobre idênticas questões de direito. Nesse diapasão, um dos principais eixos do novo Código de Processo Civil (Lei 13.105/2015) consiste na valorização de precedentes dotados de eficácia vinculante, dentre estes o incidente de resolução de demandas repetitivas (IRDR), objeto do presente artigo. Trata-se de uma das grandes novidades incorporadas ao direito processual brasileiro, de domínio obrigatório pelos operadores do direito. Analisa-se, na íntegra, o procedimento desse incidente processual. Projeta-se sua eficiência e utilidade no propósito de conferir maior previsibilidade à tutela dos direitos.

Palavras-Chave: Novo Código de Processo Civil - Lei 13.105/2015 - Incidente de Resolução de Demandas Repetitivas - Ações repetitivas - Isonomia processual.

ABSTRACT: The current scenario is one of clear incompatibility between litigation and the Judiciary's capacity to absorb such demand. The well-known problem of lengthy proceedings is aggravated by lack of predictability of the jurisdiction in the settlement of identical matters of law. In this context, one of the axes of the new Code of Civil Procedure (Law 13,105/2015) consists of valuing precedents with binding effectiveness, among them

\footnotetext{
${ }^{1}$ Artigo recebido em 30/09/2015 e aprovado em 27/11/2015.
} 
Revista Eletrônica de Direito Processual - REDP. Volume 16. Julho a dezembro de 2015

Periódico Semestral da Pós-Graduação Stricto Sensu em Direito Processual da UERJ

Patrono: José Carlos Barbosa Moreira. ISSN 1982-7636. pp. 211-239 http://www.e-publicacoes.uerj.br/index.php/redp/index

the incident of settlement of repetitious claims, which is the subject matter of this article. It is one of the major innovations in Brazilian procedural law. The proceeding of this procedural incident is analyzed in full. Its efficiency and usefulness are projected in its purpose of providing greater predictability to the protection of rights.

KeYwords: New Code of Civil Procedure - Law 13,105/2015 - Incident of Settlement of Repetitious Claims - Repetitious actions - Procedural equality.

SUMÁRIO: 1. Introdução - 2. Massificação dos litígios e o problema das demandas individuais repetitivas - 3. O IRDR como um dos instrumentos de solução ao problema das demandas repetitivas e da falta de estabilidade da jurisdição - 4. Fundamentação constitucional do IRDR - 5. Admissibilidade, processamento e julgamento do IRDR - 6. Eficácia vinculante do IRDR no contexto da crescente valorização dos precedentes - 07. O IRDR como ferramenta de racionalidade e eficiência da prestação jurisdicional - 08. Conclusões - 09. Referências bibliográficas.

\section{INTRODUÇÃo}

Encerrado o trâmite em torno da aprovação do projeto do novo Código de Processo Civil (CPC/2015), com a sanção presidencial e promulgação da Lei 13.105/2015, deslocase o eixo de análise. Evolui-se da etapa das proposições e lamentações do que deveria ter sido alterado ou daquilo que fora deixado de lado pelo legislador para uma análise objetiva em torno do texto aprovado pelo Poder Legislativo. Para agrado ou desagrado do jurista ou mesmo do cidadão importa neste momento voltar os olhos para o presente (Lei 13.105/2015) e projetar o futuro. Esta é a ótica de nosso breve estudo. Analisar o novo, com as lentes voltadas ao chamado incidente de resolução de demandas repetitivas e projetar sua eficácia - ou ineficácia - enquanto solução pensada pelo CPC/2015 ao problema da massificação dos litígios e da consequente multiplicação de processos sobre idêntica questão de direito.

\section{MASSIFICAÇÃO DOS LITÍGIOS E O PROBLEMA DAS DEMANDAS INDIVIDUAIS}

\section{REPETITIVAS}


Revista Eletrônica de Direito Processual - REDP. Volume 16. Julho a dezembro de 2015

Periódico Semestral da Pós-Graduação Stricto Sensu em Direito Processual da UERJ

Patrono: José Carlos Barbosa Moreira. ISSN 1982-7636. pp. 211-239 http://www.e-publicacoes.uerj.br/index.php/redp/index

A criação de um mecanismo de resolução de demandas repetitivas pelo legislador processual deve partir de um pressuposto fático preocupante e de inegável existência: o crescimento incessante da litigiosidade e a incapacidade da estrutura judiciária brasileira frente a esta demanda vertiginosa.

As causas deste abarrotamento de processos são as mais diversas. Razões de ordem social, cultural e econômica explicam o fenômeno. Pode-se destacar, dentre outras, à privatização e consequente universalização dos serviços públicos, à maior conscientização do consumidor em relação aos seus direitos, o inchaço do número de advogados em nível nacional, fruto da proliferação das Faculdades de Direito, a ampliação do acesso ao crédito, o maior poder de consumo das classes menos favorecidas e, ainda, o papel do Estado como demandado protagonista, ao não honrar as suas dívidas, deixar de prestar serviço público ou prestá-lo com má qualidade, por cobrar tributos indevidos, dentre outros tantos inadimplementos. $^{2}$

O Conselho Nacional de Justiça revela que a quantidade de casos pendentes de solução definitiva (estoque de processos) nos tribunais brasileiros tem crescido, em média, 3,4\% por ano desde 2009. Em 2013, o número de processos acumulados e que aguardavam uma decisão final no Judiciário chegou a 66,8 milhões. ${ }^{3}$

O panorama atual é de visível incompatibilidade entre litigiosidade e a capacidade do Poder Judiciário em absorver tal demanda. Mais do que um problema de natureza processual, trata-se de um problema de Estado, que presta jurisdição morosa, descumprindo direito fundamental do cidadão ${ }^{4}$. Trata-se, ainda, de um problema de governo, vez que parte da solução deveria advir de um melhor aparelhamento do Judiciário, em nível federal e especialmente estadual.

Curioso constatar que a facilitação do acesso à justiça verificado nas últimas décadas sob o estímulo do Estado, em realização de sua própria incumbência constitucional ${ }^{5}$, com

\footnotetext{
${ }^{2}$ A respeito da massificação dos litígios, ver Guilherme Rizzo Amaral. Efetividade, segurança, massificação e a proposta de um incidente de coletivização. In Processo Coletivo e outros temas de direito processual: homenagem 50 anos de docência do professor José Maria Rosa Tesheiner e 30 anos de docência do Professor Sérgio Gilberto Porto. Livraria do Advogado. Porto Alegre, 2012, p. 237-259.

${ }^{3}$ Os dados constam da décima edição do Relatório Justiça em Números, elaborado anualmente pelo Conselho Nacional de Justiça (CNJ) e que faz um diagnóstico completo dos 112 tribunais existentes no país, contando cortes superiores, federais, estaduais, trabalhistas, eleitorais e militares, com exceção do Supremo Tribunal Federal (STF), a mais alta instância do Judiciário.

${ }^{4} \mathrm{CF}$, art. $5^{\circ}$, LXXVIII: "a todos, no âmbito judicial e administrativo, são assegurados a razoável duração do processo e os meios que garantam a celeridade de sua tramitação."

${ }^{5} \mathrm{O}$ acesso à justiça é um direito fundamental básico do cidadão e imprescindível para o desenvolvimento do um país. A Constituição de 1988 consagrou o princípio do acesso à justiça, que engloba em seu aspecto formal
} 
Revista Eletrônica de Direito Processual - REDP. Volume 16. Julho a dezembro de 2015

Periódico Semestral da Pós-Graduação Stricto Sensu em Direito Processual da UERJ

Patrono: José Carlos Barbosa Moreira. ISSN 1982-7636. pp. 211-239 http://www.e-publicacoes.uerj.br/index.php/redp/index

medidas exitosas como o fortalecimento das defensorias públicas, ampla concessão da gratuidade da justiça, implementação do procedimento sumaríssimo (juizados especiais) ${ }^{6}$, é justamente uma das principais causas do abarrotamento do Judiciário. A ampliação do acesso à justiça desacompanhado de uma gestão eficiente acarretou prejuízo à qualidade e à tempestividade da jurisdição. A solução virou problema. O Estado não está obrigado a prestar qualquer jurisdição mas uma tutela justa, efetiva e adequada. Como sabido, a garantia do acesso à justiça não se resume a acessar o Judiciário em busca de tutela (acesso formal) ${ }^{7}$, mas a receber uma resposta efetiva e tempestiva, representativa do conceito atual do acesso à justiça em sentido material e substancial. ${ }^{8} 9$

É de se reconhecer, inclusive, que a Constituição Federal de 1988 ao assegurar inúmeros direitos fundamentais ao cidadão, dotados de eficácia em maior ou menor grau, criou as condições para o cidadão exigisse judicialmente seus direitos sociais constitucionalmente reconhecidos. Trata-se, em síntese, de fenômeno próprio do Estado

\footnotetext{
a garantia de inafastabilidade da jurisdição, em seu art. $5^{\circ}$, inciso XXXV: "a lei não excluirá da apreciação do Poder Judiciário lesão ou ameaça a direito".

${ }^{6}$ Lei 9.099/2001 (Dispõe sobre a instituição dos Juizados Especiais Cíveis e Criminais no âmbito da Justiça Federal) e Lei 10.259/2001 (Dispõe sobre a instituição dos Juizados Especiais Cíveis e Criminais no âmbito da Justiça Federal).

7 “[...] a noção de acesso à justiça ganha contorno qualificado na consecução da tutela jurisdicional, no momento em que a simples presença de órgãos jurisdicionais previstos na Constituição ou na legislação infraconstitucional não é suficiente para o seu completo alcance. É necessário ir além, de modo a que não se tenha uma diretriz vazia e sem aplicação. Trata-se do alcance da noção de justiça material na prestação jurisdicional, que pode ser entendida como a necessária efetividade da tutela jurisdicional, tema que será devidamente abordado no item a seguir." (VALCANOVER, Fabiano Haselof. O princípio do acesso à justiça após a Emenda Constitucional no 45/2004. Revista Páginas de Direito, Porto Alegre, ano 14, $\mathrm{n}^{\circ} 1104,30 \mathrm{de}$ janeiro de 2014. Disponível em: http://www.tex.pro.br/home/artigos/259-artigos-jan-2014/6386-o-principiodo-acesso-a-justica-apos-a-emenda-constitucional-n-45-2004)

8 "A constatação de que é da essência da cidadania a garantia de que a todos será assegurado o mais amplo acesso à Justiça foi incorporada ao longo do século XX. A mera proclamação de acesso democrático, conquanto importante, não basta, por si só, para garantir o êxito no projeto, que depende fundamentalmente da mentalidade dos operadores envolvidos e do permanente ânimo de realizar o direito. A partir dessa perspectiva, a norma constitucional que assegura a apreciação de lesão ou de ameaça a direito (art. $5^{\circ}, \mathrm{XXXV)}$ é a base do direito processual brasileiro, merecendo aplicação imediata e consideração em toda e qualquer discussão judicial." (PORTO, Sérgio Gilberto. USTÁRROZ, Daniel. Lições de Direitos Fundamentais no Processo Civil. Porto Alegre: Livraria do Advogado Editora, 2009. p. 41)

9 "O exercício constitucional da cidadania está, assim, a depender da possibilidade de acesso à jurisdição, pressupondo participação efetiva e paritária no processo. Além de exigir um poder judiciário firmemente estruturado e independente, com amplas atribuições, inclusive a de exercer jurisdição constitucional, o acesso à justiça impõe a criação de institutos que tornem possível equilibrar ou minorar o efeito de diferenças de ordem material, potencialmente excludentes de indivíduos ou grupos. A proteção jurídica individual e coletiva é, assim, condição mesma de existência do Estado de Direito e pressupõe "justo e adequado acesso à jurisdição", além de uma ordem processual que se encarregue de concretizar o direito "segundo os meios e métodos de um processo juridicamente adequado." (FLACH, Daisson. Processo e realização constitucional: a construção do "devido processo". In Amaral, Rizzo Guilherme; Carpena, Marcio Louzada (coord.). Visões críticas do processo civil brasileiro. Porto Alegre: Livraria do Advogado, 2005. p. 22)
} 
Revista Eletrônica de Direito Processual - REDP. Volume 16. Julho a dezembro de 2015

Periódico Semestral da Pós-Graduação Stricto Sensu em Direito Processual da UERJ

Patrono: José Carlos Barbosa Moreira. ISSN 1982-7636. pp. 211-239 http://www.e-publicacoes.uerj.br/index.php/redp/index

Democrático de Direto, decorrente da socialização dos direitos, da incapacidade do Estado em assegurá-los materialmente e da consequente judicialização destas pretensões.

Vive-se, hodiernamente, um período de hipertrofia quantitativa de processos, não apenas no Brasil, mas em diversas democracias do mundo ocidental. ${ }^{10}$ Ao conhecido problema da morosidade - que fere a duração razoável do processo (tempestividade ${ }^{11}$ ) anunciada constitucionalmente ${ }^{12}$ - soma-se outro prejuízo, bem observado pelo legislador do novo código (Lei 13.105/2015), qual seja: a falta de previsibilidade da jurisdição na solução de demandas sobre idênticas questões de direito. O prejuízo, nestes casos, vai de encontro aos princípios constitucionais da isonomia processual e da segurança jurídica.

É certo, entretanto, que o direito processual deverá dar sua parcela de contribuição à solução deste grave problema. Ao legislador processual caberá prever mecanismos voltados a incrementar a racionalidade e eficiência do processo. Aos operadores do direito caberá bem compreendê-los e aplicá-los. Nessa ordem de ideias, o legislador acena com um novo Código de Processo, que dentre outras tantas inovações, cria e disciplina o chamado incidente de resolução de demandas repetitivas, em seus artigos 976 a 987.

Dentre outras consequências da massificação das relações em sociedade verifica-se constante proliferação de demandas individuais sobre idêntica questão de direito e o problema, daí decorrente, de decisões diametralmente opostas sobre esta idêntica controvérsia.

\footnotetext{
${ }^{10}$ Zanferdini, Flávia de Almeida Montingelli; Gomes, Alexandre Gir. Tratamento coletivo adequado das demandas individuais repetitivas pelo juízo de primeiro grau. Revista de Processo. Ano 39, vol. 234, agosto, 2014. Revista dos Tribunais. p. 181-207.

${ }^{11}$ Marco Felix Jobim esclarece a necessária distinção entre celeridade e tempestividade no âmbito do processo: "A duração razoável do processo tem por finalidade a garantia ao jurisdicionado que ingressa no Poder Judiciário de que, em determinado tempo, e que este seja razoável, o seu processo tenha sido efetivado, ou pelo menos tenha sua sentença transitado em julgado. Já a celeridade processual é garantia ao jurisdicionado de que os atos processuais sejam realizados no menor espaço de tempo possível, numa linha de economia processual. (... ) ter um processo intempestivo não quer dizer que não houve celeridade em várias partes de seu procedimento, não podendo os princípios serem confundidos como o vem sendo." (JOBIM, Marco Félix. $O$ direito fundamental à duração razoável do processo e a responsabilidade civil do Estado em decorrência da intempestividade processual. 2. ed. rev. e ampl. Porto Alegre: Livraria do Advogado Editora, 2012.

${ }^{12}$ José Maria Tesheiner faz instigante crítica em relação à desejada celeridade na prolação de sentenças: "Sentenças não podem nem devem ser produzidas na velocidade com que se expedem carteiras de identidade. Julgamentos não são despachos burocráticos que se possam proferir automaticamente, como reflexos pavlovianos. Valorizam-se os magistrados, não pelo sabedoria de suas julgamentos, mas pela quantidade de suas decisões. Decisões ruins não geram a desejada paz social; geram novos conflitos." (Celeridade ou tempestividade processuais? Processos Coletivos. Revista Eletrônica - Porto Alegre, ano 2015, v. 6, n. 3, julho a setembro. Disponível em http://www.processoscoletivos.net/ pcoletiv/ponto-e-contraponto/726celeridade-ou-tempestividade-processuais.)
} 
Revista Eletrônica de Direito Processual - REDP. Volume 16. Julho a dezembro de 2015

Periódico Semestral da Pós-Graduação Stricto Sensu em Direito Processual da UERJ

Patrono: José Carlos Barbosa Moreira. ISSN 1982-7636. pp. 211-239 http://www.e-publicacoes.uerj.br/index.php/redp/index

$\mathrm{O}$ ideal da equidade, previsto em sede constitucional e buscado pelo novo diploma processual, está justamente em distribuir jurisdição idêntica para casos que apresentam idêntica controvérsia de direito, mediante uma sistemática própria de precedentes, na qual insere-se o incidente de resolução de demandas repetitivas. A força do precedente em favor da equidade é bem destacada por Ronald Dworkin ${ }^{13}$ :

"A força gravitacional do precedente não pode ser apreendida por nenhuma teoria que considere que a plena força do procedente está em sua força de promulgação, enquanto uma peça de legislação. (...) A força gravitacional de um precedente pode ser explicada por um apelo, não à sabedoria da implementação de leis promulgadas, mas à equidade que está em tratar os casos semelhantes do mesmo modo."

Exemplifique-se o problema. Discute-se a legalidade da cobrança de determinado encargo que passou a ser exigido por diversas concessionárias de telefonia. O Tribunal de Justiça do Acre passa a decidir pela legalidade da cobrança. Perante o Tribunal de Justiça de Santa Catarina, contudo, começam a proliferar acórdãos entendendo pela ilegalidade de cobrança. Determinado juiz da Comarca de Canoas, município do Rio Grande do Sul, decide pela legalidade ao passo que juiz de Salvador posiciona-se pela ilegalidade. O juiz titular do $1^{\mathrm{o}}$ juizado da $14^{\mathrm{a}}$ vara cível do foro da Comarca do Rio de Janeiro decide pela legalidade e titular do $2^{\circ}$ juizado, da mesma vara, decide pela ilegalidade. Alea jacta est, literalmente.

É certo, contudo, que decisões díspares sobre uma mesma questão de direito são naturais e até mesmo desejadas na lógica dialética do Direito. A proliferação de decisões divergentes, a multiplicação de argumentos e fundamentos sobre idêntica controvérsia fomenta o debate, amadurece a solução, proporciona o controle e atuação dos Tribunais via recurso, ao mesmo tempo em que não retira do Estado a obrigação de prestar jurisdição minimamente estável e previsível, sob pena do Sr. João ter seu pedido julgado improcedente em processo com questão de direito idêntica ao seu vizinho de porta Pedro, que teve seu pedido julgado procedente, em ação que tramitou no mesmo Tribunal.

Dia após dia, multiplicam-se demandas repetitivas, não em relação aos fatos, que costumam variar de processo para processo (data da assinatura do contrato, valor pago, etc.), mas em relação à questão de direito objeto da controvérsia, costumeiramente derivadas de relações de consumo massificadas envolvendo, exemplificativamente, instituições

\footnotetext{
${ }^{13}$ Dworking, Ronald. Levando os direitos a sério. Trad. Nelson Boeira. 3 ed. São Paulo: Martins Fontes, 2010, p. 172-173.
} 
Revista Eletrônica de Direito Processual - REDP. Volume 16. Julho a dezembro de 2015

Periódico Semestral da Pós-Graduação Stricto Sensu em Direito Processual da UERJ

Patrono: José Carlos Barbosa Moreira. ISSN 1982-7636. pp. 211-239 http://www.e-publicacoes.uerj.br/index.php/redp/index

financeiras (como não lembrar dos planos econômicos), operadoras de telefonia (cobrança de mensalidade logo surge de exemplo), servidores públicos (diferenças salariais de determinada categoria ajustam-se ao caso).

Como parte do problema impõe-se reconhecer que o Código vigente (Lei 5.869/73) fora idealizado sob matizes individualistas. Não fora concebido para solucionar e pacificar litígios coletivos, indivisíveis e transindividuais ${ }^{14}$, tampouco demandas repetitivas sobre direitos individuais homogêneos. Os direitos individuais homogêneos, divisíveis por natureza, são aqueles ordinariamente presentes nos processos multiplicados, responsáveis por provocar, em certos casos, verdadeiras avalanches ou tsunamis processuais sobre o Judiciário, todos apresentado idêntica controvérsia (questão de direito). Trata-se, portanto, de um código de processo individual. Os direitos genuinamente coletivos - difusos e coletivos stricto sensu - são tutelados mediante o microssistema do processo coletivo, formado por normas processuais esparsas presentes na lei da Ação Civil Pública (Lei 7.347/85), no Código de Defesa do Consumidor (Lei 8.078/90) e no mandado de segurança coletivo (Lei 12.016/2009).

Ocorre que este microssistema do processo coletivo brasileiro apresenta características que o tornam ineficiente à tutela de direito individuais homogêneos, desde a restrição dos legitimados ativos, passando pela limitação da eficácia territorial da sentença e finalmente pela impossibilidade da sentença fazer coisa julgada contrária aos interesses dos interessados - coisa julgada secundum eventum litis (LACP, art. 16 e CDC, art. 103, I e II) e coisa julgada secundum eventum probationes (CDC, art. 103, III) - permitindo a convivência de ações

\footnotetext{
${ }^{14}$ Direitos ou interesses difusos e coletivos (coletivos lato sensu) e direitos ou interesses individuais homogêneos constituem categorias de direitos diferenciadas. A conceituação destes, depois de sedimentada na doutrina, foi convertida em texto normativo (art. 81, parágrafo único, da Lei 8.078/90). Segundo o legislador, são direitos difusos os transindividuais, de natureza indivisivel, de que sejam titulares pessoas indeterminadas e ligadas por circunstâncias de fato (art. 81, parágrafo único, I); são direitos coletivos os transindividuais de natureza indivisivel, de que seja titular grupo, categoria ou classe de pessoas ligadas entre si ou com a parte contrária por uma relação jurídica base (inciso II); e são direitos individuais homogêneos os decorrentes de origem comum (inciso III). Direitos difusos e coletivos são, portanto, direitos subjetivamente transindividuais (sem titular individualmente determinado) e materialmente indivisiveis (titularidade múltipla, coletiva). A expressão direito coletivo é designação genérica a compreender duas modalidades de direitos transindividuais: o difuso e o coletivo stricto sensu. Trata-se de uma categoria de direito material relativamente nova, nascida da superação da clássica dicotomia entre interesse público e interesse privado. De outro lado, os direitos individuais homogêneos são, simplesmente, direitos subjetivos individuais. A qualificação de homogêneos não altera a sua natureza individual. Cuida-se de um conjunto de direitos subjetivos individuais ligados entre si por uma relação de afinidade, de homogeneidade, que propicia, embora não imponha, a defesa coletiva de todos eles. (ZAVASCKI, Teori Albino. Processo Coletivo: Tutela de Direitos Coletivos e Tutela Coletiva de Direitos. 2. ed. São Paulo: Revista dos Tribunais, 2007. p. 57).
} 
Revista Eletrônica de Direito Processual - REDP. Volume 16. Julho a dezembro de 2015

Periódico Semestral da Pós-Graduação Stricto Sensu em Direito Processual da UERJ

Patrono: José Carlos Barbosa Moreira. ISSN 1982-7636. pp. 211-239 http://www.e-publicacoes.uerj.br/index.php/redp/index

individuais desvinculadas da coisa julgada obtida na ação coletiva, em prejuízo da racionalidade e da pretendida unidade do direito.

A problemática da repetitividade de demandas com idêntica questão de direito requer a formação de um precedente vinculante às ações individuais em andamento, aspecto que também não é resolvido pelo processo coletivo, diante da possibilidade do autor de ação individual prosseguir com a sua demanda, sem submeter-se à tese firmada na ação civil pública. Registre-se, ainda, que as ações coletivas não admitem pretensão relacionada a tributos, contribuições previdenciárias, fundo de garantia por tempo de serviço (FGTS) ou outros fundos institucionais (Lei $7.345 / 85$, art. $1^{\circ}$ ), temas que por sua natureza despertam interesses individuais homogêneos.

\section{O IRDR COMO UM DOS INSTRUMENTOS DE SOLUÇÃO AO PROBLEMA DAS} DEMANDAS REPETITIVAS E DA FALTA DE ESTABILIDADE DA JURISDIÇÃO

O novo Código de Processo Civil reconhece, de modo expresso, sua função de concretizar o modelo constitucional de jurisdição e do processo, a servir de instrumento idôneo para a solução de conflitos e tutela adequada dos mais variados direitos, aí incluídos os direitos individuais homogêneos, presentes no fenômeno da proliferação de demandas repetitivas.

Nesse diapasão, um dos principais eixos do novo Código de Processo Civil consiste na valorização de precedentes, mediante diferentes mecanismos, todos vinculantes, dentre estes o incidente de resolução de demandas repetitivas (IRDR) objeto do presente artigo. Privilegia-se, aqui, o valor segurança jurídica valorizando-se a previsibilidade e a estabilidade das decisões judiciais. Neste incremento da autoridade dos precedentes judiciais percebe-se certa aproximação entre os sistemas jurídicos da civil law e da common law. ${ }^{15}$

Como informa a exposição de motivos do Lei 13.105/2015, “criaram-se figuras, no novo CPC, para evitar a dispersão excessiva da jurisprudência. Com isso, haverá condições

\footnotetext{
15 "Pois bem, é exatamente essa aproximação entre os sistemas da civil law e da common law que aponta para a necessidade de o sistema de civil law conter a possibilidade de arbítrio judicial e dar segurança jurídica aos seus jurisdicionados." (Marinoni, Luiz Guilherme; Arenhart, Sérgio Cru; Mitidiero, Daniel. Novo curso de processo civil: teoria do processo civil, volume 1. Editora Revista dos Tribunais, 2015, p. 147)
} 
Revista Eletrônica de Direito Processual - REDP. Volume 16. Julho a dezembro de 2015

Periódico Semestral da Pós-Graduação Stricto Sensu em Direito Processual da UERJ

Patrono: José Carlos Barbosa Moreira. ISSN 1982-7636. pp. 211-239 http://www.e-publicacoes.uerj.br/index.php/redp/index

de se atenuar o assoberbamento de trabalho no Poder Judiciário, sem comprometer a qualidade da prestação jurisdicional." 16

Ao criar o incidente de resolução de demandas repetitivas o legislador optou por uma terceira via de tutela. Não se trata, portanto e como veremos, de processo individual mediante procedimento comum, tampouco de processo coletivo, optou-se por instituir um incidente específico, instaurado a partir de um processo individual representativo da controvérsia, para firmar o precedente vinculante para a tutela uniforme de direitos individuais repetitivos e homogêneos, disciplinado nos artigos 976 a 986 do CPC/2015. ${ }^{17}$

Desse modo, o IRDR destina-se a trazer solução parcial aos males de insegurança jurídica, associados à ausência de previsibilidade e estabilidade da jurisdição diante de demandas individuais repetitivas, com idêntica questão de direito. Trata-se de incidente em demanda individual (causa-piloto) vocacionado para firmar a tese jurídica a respeito de determinada controvérsia. ${ }^{18}$

Extrai-se da exposição de motivos do CPC/2015 reconhecida inspiração no procedimento similar alemão chamado Musterverfahren, em que pese existam diferenças significativas na comparação.

Podemos definir o incidente de resolução de demandas repetitivas como um incidente processual voltado à uniformização da jurisdição, mediante a estabilização da tese jurídica firmada em precedente vinculante, representativo de controvérsia repetida em outros processos individuais, que versam sobre a mesma questão de direito.

Trata-se de uma das grandes novidades incorporadas ao direito processual brasileiro pelo CPC/2015, instituto de domínio obrigatório pelos operadores do direito.

\section{FUNDAMENTAÇ̃̃O CONSTITUCIONAL DO IRDR}

\footnotetext{
${ }^{16}$ Comissão de juristas responsável pela elaboração do anteprojeto do Código de Processo Civil. Código de Processo Civil: anteprojeto. Brasília: Senado Federal, 2010.

${ }^{17}$ Quando se fala em tutela de direitos coletivos está-se referindo à tutela dos direitos difusos e coletivos em sentido estrito, por meio dos instrumentos do processo coletivo. Já a tutela coletiva de direitos diz respeito à aplicação facultativa desses instrumentos aos direitos individuais homogêneos, quando seu titular não pretenda valer-se do processo individual. Como veremos, o incidente de resolução de demandas repetitivas apresentase como mecanismo processual adequado a tutela de direitos individuais homogêneos multiplicados em demandas repetitivas, instrumento este voltado à uniformização de entendimento, fixação de tese ou criação de precedente vinculante.

${ }^{18}$ Sem desviar-nos de nosso propósito, cabe rapidamente registrar nosso descontentamento com a supressão da projetada aplicação do IRDR na solução de idênticas questões de fato. Ao que nos parece, perdeu-se boa oportunidade para otimizar a utilidade do incidente, ampliando-se o campo de atuação do novel instituto.
} 
Revista Eletrônica de Direito Processual - REDP. Volume 16. Julho a dezembro de 2015

Periódico Semestral da Pós-Graduação Stricto Sensu em Direito Processual da UERJ

Patrono: José Carlos Barbosa Moreira. ISSN 1982-7636. pp. 211-239 http://www.e-publicacoes.uerj.br/index.php/redp/index

$\mathrm{O}$ objetivo do novo incidente de resolução de demandas repetitivas consiste em assegurar garantias constitucionais de primeira ordem no âmbito do processo civil, quais sejam: segurança jurídica, isonomia e duração razoável do processo.

Partindo-se da contextualização de nossa sociedade atual - já assinalada no primeiro capítulo - constatam-se inúmeras causas a justificar o abarrotamento de nosso judiciário. Nossa sociedade é predominante urbana, submetida a relações de consumo massificadas, fruto do desenvolvimento da indústria, do avanço das tecnologias e da velocidade das transações em uma economia de mercado. Esta realidade social é um dos principais fatores para o vertiginoso aumento da litigiosidade, que exige do processo respostas cada vez mais eficazes e seguras - e não apenas ágeis - a fim de bem adequar-se a ordem social.

Atenta a tal realidade, o rol de garantias constitucionais foi ampliado por força de emenda constitucional 45/2014, garantindo a todos, no plano ideal dos princípios, "a razoável duração do processo e os meios que garantam a celeridade de sua tramitação." Imbuído desse propósito, o CPC/1973 recebeu inúmeras reformas voltadas a incrementar a efetividade, entendida como aptidão do processo em produzir resultados.

Foi e será preciso racionalizar a distribuição da tutela jurisdicional, cuidando-se de solucionar questões de direito repetitivas de modo eficiente, assegurando igualdade, previsibilidade e relativa estabilidade na resposta jurisdicional, tutelando de forma idêntica controvérsias jurídicas idênticas, típicas da sociedade de massa, sob pena de grave descrédito do sistema judicial de resolução de conflitos. Concorda-se com o diagnóstico de que "sendo o processo instrumento de pacificação social, a adoção de soluções jurídicas diversas para uma mesma situação jurídica acarreta inegável insegurança jurídica, incerteza do direito e efetivo descrédito no Poder Judiciário." 19

A tentativa de solução processual deu-se, em grande parte, pelo caminho da valorização da jurisprudência, adotada como precedente, verificável como dominante ou transformada em súmula. Em sede constitucional viu-se a implantação das súmulas vinculantes, do controle concentrado de constitucionalidade e da repercussão geral. No âmbito do CPC/2015 previu-se, dentre outros, a sistemática dos recursos repetitivos, o julgamento monocrático por obediência a sumula ou jurisprudência dominante, a sentença liminar, a súmula impeditiva de recurso. Nesse objetivo, a grande contribuição do Novo

19 Zanferdini, Flávia de Almeida Montingelli. Gomes, Alexandre Gir. Tratamento coletivo adequado das demandas individuais repetitivas pelo juízo de primeiro grau. Revista de Processo. Ano 39, vol. 234, agosto, 2014. Revista dos Tribunais. p. 181-207. 
Revista Eletrônica de Direito Processual - REDP. Volume 16. Julho a dezembro de 2015

Periódico Semestral da Pós-Graduação Stricto Sensu em Direito Processual da UERJ

Patrono: José Carlos Barbosa Moreira. ISSN 1982-7636. pp. 211-239 http://www.e-publicacoes.uerj.br/index.php/redp/index

Código de Processo Civil deu-se com o incidente de resolução de demandas repetitivas (IRDR), dotado de identidade e características próprias, mas com traços marcantes de institutos próximos do direito estrangeiro.

Referido incidente parte da premissa de que, em sede de demandas repetitivas, uniformizar é preciso. O IRDR busca, pelo procedimento já analisado, implementar exigências constitucionais de igualdade e segurança jurídica, relacionadas à previsibilidade da atuação do Estado em face do particular, exigindo interpretações mais estáveis e melhor fundamentadas (art. $489, \S 1^{\circ}$ ), na contramão do arbítrio estatal. ${ }^{20}$ Busca atender ao anseio social - e do mercado - de conferir o mínimo de previsibilidade à tutela jurisdicional. Com marcante contundência, à qual nos associamos, Marinoni afirma ${ }^{21}$ :

"É chegado o momento de se colocar o ponto final no cansativo discurso de que o juiz tem a liberdade ferida quando obrigado a decidir e acordo com os tribunais superiores. $\mathrm{O}$ juiz, além da liberdade para julgar, tem dever para com o Poder de que faz parte e para com o cidadão. Possui o dever de manter a coerência do ordenamento e de zelar pela respeitabilidade e pela credibilidade do Poder Judiciário."

$\mathrm{O}$ CPC/2015 não deixa dúvida a respeito do propósito constitucional do incidente de resolução de demandas repetitivas: (i) "conferir previsibilidade e segurança jurídica à Jurisdição" e (ii) "preservar a isonomia no âmbito do processo". Parte-se de premissa, destacada por Rizzo Amaral, de que "não apenas a lei, como também a jurisprudência deve ser clara e previsível, sendo ameaçadoras da segurança jurídica as decisões exóticas e surpreendentes." 22

O IRDR estabelece verdadeiro rompimento com o paradigma individualista do CPC/1973, guardando obediência aos preceitos constitucionais da duração razoável do processo, da segurança jurídica e da isonomia processual, a partir de um tratamento uniforme

\footnotetext{
${ }^{20}$ Rizzo Amaral esclarece que segurança jurídica é um valor inerente ao Estado de Direito, e é vista na doutrina não só como a garantia do cidadão contra o arbítrio estatal, mas também como a previsibilidade da atuação do Estado em face do particular, exigindo para si, regras fixas. Sua presença, ora como valor, ora como princípio, ou assumindo outras facetas, é constante nos países democráticos do mundo inteiro. (Amaral, Guilherme Rizzo. Efetividade, segurança, massificação e a proposta de um incidente de coletivização. In Processo Coletivo e outros temas de direito processual: homenagem 50 anos de docência do professor José Maria Rosa Tesheiner e 30 anos de docência do Professor Sérgio Gilberto Porto. Livraria do Advogado. Porto Alegre, 2012, p. 237259.)

${ }^{21}$ Marinoni, Luiz Guilherme. Precedentes obrigatórios. $2^{\mathrm{a}}$ ed. rev. e atual. São Paulo: ED. RT, 2011, p. 65.

22 Amaral, Guilherme Rizzo. Efetividade, segurança, massificação e a proposta de um incidente de coletivização. In Processo Coletivo e outros temas de direito processual: homenagem 50 anos de docência do professor José Maria Rosa Tesheiner e 30 anos de docência do Professor Sérgio Gilberto Porto. Livraria do Advogado. Porto Alegre, 2012, p. 237-259.
} 
Revista Eletrônica de Direito Processual - REDP. Volume 16. Julho a dezembro de 2015

Periódico Semestral da Pós-Graduação Stricto Sensu em Direito Processual da UERJ

Patrono: José Carlos Barbosa Moreira. ISSN 1982-7636. pp. 211-239 http://www.e-publicacoes.uerj.br/index.php/redp/index

na resolução de questões de direito e na distribuição da justiça. Vale referir as palavras de Karl Larenz: "por detrás do critério da uniformidade da jurisprudência está o postulado de justiça que consiste em decidir o que é idêntico de modo idêntico." ${ }^{23} \mathrm{O}$ tempo dirá a respeito de eficiência do IRDR, abrindo desejável espaço, neste momento, para projeções de parte da doutrina.

\section{ADMISSIBILIDADE, PROCESSAMENTO E JULGAMENTO DO IRDR}

A instauração do incidente de resolução de demandas repetitivas (IRDR) exige como pressupostos de sua admissibilidade a presença, simultânea, de três requisitos indispensáveis (art. 976), (i) efetiva repetição de processos, (ii) controvérsia sobre idêntica questão de direito e (iii) risco de ofensa às garantias constitucionais da isonomia e da segurança jurídica.

A nosso ver, o risco de ofensa à isonomia decorrente de decisões díspares sobre idêntica questão de direito estará sempre presente diante da proliferação de demandas repetitivas. O risco à isonomia, portanto, será uma decorrência natural dos pressupostos legais antecedentes (demandas repetitivas e controvérsia sobre idêntica questão de direito). Diante da proliferação de dezenas, centenas, milhares de processos sobre idêntica questão de direito será difícil negar o risco de decisões divergentes, a partir da natural abertura do direito, do emprego de conceitos indeterminados, do princípio do livre convencimento, da diversidade de princípios invocáveis, da possível colisão entre normas, ou seja, dentre tantas intepretações e respostas possíveis.

Em razão do interesse público em atribuir previsibilidade à jurisdição, o $\S 1^{\circ}$ do art. 976 revela que a desistência ou abandono do processo pelo autor não impedirá o exame do mérito do incidente uma vez instaurado e admitido. É que, sob pena de ofensa ao princípio do dispositivo, não se poderia obrigar o autor a prosseguir com a sua demanda, não obstante o interesse público despertado. Pela mesma razão (interesse público), caso não seja o requerente, haverá intervenção obrigatória do Ministério Público, que assumirá a titularidade do incidente em caso de abandono ou desistência pelo autor originário $\left(\S 2^{\circ}\right)$. Pelo mesmo motivo (interesse público), o IRDR não está sujeito ao pagamento de custas $\left(\S 5^{\circ}\right)$. A participação do parquet fundamenta-se no art. 127 da Constituição Federal, bem como no

\footnotetext{
${ }^{23}$ Larenz, Karl. Metodologia da ciência do direito. $2^{\mathrm{a}}$ ed. Tradução José de Souza e Brito e José Antônio Veloso. Lisboa: Fundação Calouste Gulbekian, 1969, p. 502.
} 
Revista Eletrônica de Direito Processual - REDP. Volume 16. Julho a dezembro de 2015

Periódico Semestral da Pós-Graduação Stricto Sensu em Direito Processual da UERJ

Patrono: José Carlos Barbosa Moreira. ISSN 1982-7636. pp. 211-239 http://www.e-publicacoes.uerj.br/index.php/redp/index

art. 178 do CPC/2015, uma vez presente evidente relevância social no incidente. Caso instaurado e admitido, o incidente fatalmente atingirá o seu fim, fixando tese vinculante (precedente à brasileira ${ }^{24}$ ) a respeito da controvérsia de direito repetitiva.

Interessa observar a preocupação do legislador para com a coerência do microssistema de vinculação aos precedentes (art. 927) ao dispor que será incabível o IRDR quando tribunal superior já tiver afetado recurso repetitivo (arts. 1.036 a 1.042) sobre a mesma questão de direito objeto do incidente posteriormente instaurado (art. 976, $\S 4^{\circ}$ ). Neste caso, em favor da racionalidade da jurisdição, prevalecerá a decisão do recurso repetitivo somente porque afetado anteriormente, uma vez que inexiste hierarquia entre tais mecanismos de uniformização de jurisprudência, inseridos - não por acaso - no mesmo inciso do art. 927, ao estabelecer a ordem dos precedentes à brasileira. ${ }^{25}$

A propósito, em breve parêntesis, a expressão precedentes à brasileira bem denota a existência de uma sistema de precedentes único, com peculiaridades distintas daquelas observadas em países com maior tradição no assunto. Verifica-se, exemplificativamente, em relação ao IRDR, um precedente fruto de um único julgamento e cuja decisão será de aplicação obrigatória a todos os demais, em qualquer grau de jurisdição, sob pena de reclamação ao órgão jurisdicional que firmou o precedente. Já em relação às súmulas, presentes no topo da cadeia do sistema de uniformização brasileiro, impõe-se admitir sua pobreza de sentido diante da riqueza presente na ratio decidendi de um precedente. As súmulas são naturalmente generalizantes e abstratas, especialmente se ignorados os julgados que lhe deram sustentação. Como bem adverte Lênio Luiz Streck acerca do objetivismo das súmulas, eles são "respostas a priori, oferecidas antes das perguntas", são uma espécie "de 'antecipação de sentido, uma 'tutela antecipatória das palavras', ou, ainda, uma atribuição de sentido inaudita altera parte. $\mathrm{O}$ tema escapa aos modestos limites do presente artigo e

\footnotetext{
${ }^{24}$ A esse respeito, O precedente à brasileira: súmula vinculante e o incidente de resolução de demandas repetitivas. Rossi, Júlio César. Revista de Processo, ano 37, vol. 208, junho/2002, p. 203-240.

${ }^{25}$ Como refere Júlio César Rossi, a prática brasileira carece de uma teorização, de uma doutrina brasileira de precedentes, sob pena de cometerem-se equívocos cruciais na sua aplicação "valorizando julgados, ou mesmo ementas de decisões, como se fossem genuínos precedentes, interpretando-os e aplicando-os de forma autônoma e desvinculada da causa (objeto) de onde foram gerados." Referido autor realiza crítica contundente à eficácia vinculante da tese firmada no incidente: "Tanto a súmula quanto o IRDR constituem simulacros de aplicação de precedentes (pouco importando o sistema jurídico dos quais provenham), pois, na medida em que preveem o mecanismo de uma ação contra decisão que os tenha aplicado, perdem o caráter orientador (construído historicamente pelo direito) e ganham, inexoravelmente, um predicado obrigatório e vinculante, totalmente descontextualizado do caso a ser enfrentado pelo Poder Judiciário." (Rossi, Júlio Cesar. $O$ precedente à brasileira: súmula vinculante e o incidente de resolução de demandas repetitivas. Revista de Processo, ano 37, vol. 208, jun/2012, p. 203-240.)
} 
Revista Eletrônica de Direito Processual - REDP. Volume 16. Julho a dezembro de 2015

Periódico Semestral da Pós-Graduação Stricto Sensu em Direito Processual da UERJ

Patrono: José Carlos Barbosa Moreira. ISSN 1982-7636. pp. 211-239

http://www.e-publicacoes.uerj.br/index.php/redp/index

requer maior aprofundamento. Ressente-se, na realidade, de uma teoria própria de precedentes conforme as particularidades do ordenamento jurídico nacional.

Quanto à legitimidade ativa para requerer a instauração do incidente (art. 977), facultase a iniciativa às partes do processo originário, ao Ministério Público à Defensoria Pública, por petição, ao juiz da causa ou ao relator em sede recursal, estes últimos mediante ofício. Consoante o parágrafo único do mesmo dispositivo, qualquer destes legitimados terá o ônus de instruir o requerimento (por ofício ou petição) com documentos suficientes à demonstração dos pressupostos de admissibilidade referidos (existência de demandas repetitivas sobre idêntica questão de direito, acrescido do risco ou efetiva ofensa à isonomia e à segurança jurídica).

Os Tribunais deverão definir em seu regimento interno qual de seus órgãos será o competente à admissibilidade, processamento e julgamento do incidente, obrigatoriamente dentre aqueles responsáveis pela uniformização de jurisprudência (art. 978). Não apenas os tribunais locais, mas os Tribunais Superiores também o farão, pois, como veremos, caberá recurso extraordinário e recurso especial dos acórdãos de segunda instância em IRDR. Tal incumbência será atribuída ao órgão especial ou órgão pleno dos Tribunais, considerando, ainda, que eventual declaração de inconstitucionalidade de lei ou ato normativo nos autos do incidente estará submetida à regra da reserva de plenário (CF, art. 97).

Necessária a ampla divulgação a respeito de todas as fases do IRDR, conferindo-lhe desejável publicidade na sua instauração, processamento e julgamento (art. 979). Tal divulgação se dará por meio de registro eletrônico no Conselho Nacional de Justiça e banco eletrônico de dados dos Tribunais, contendo informações específicas a respeito do incidente e das questões de direito nele abrangidas. Em boa medida, para uma adequada individualização da tese jurídica a ser firmada no incidente, a decisão deverá revelar, suficientemente, seus fundamentos determinantes ${ }^{26}$ e os dispositivos legais relacionados. Tal sistemática (art. 979), de ampla divulgação do trâmite do IRDR, representa, em realidade, regra geral de identificação e divulgação dos precedentes vinculantes, visto que também ocorrerá no julgamento de recurso especial e extraordinário repetitivo e extraordinário com repercussão geral reconhecida (art. 979, $\S 3^{\circ}$ ). Revela-se aí, uma vez mais, a forte carga de

\footnotetext{
${ }^{26}$ Luís Roberto Barroso ilustra o significado da expressão: “[...] por essa linha de entendimento, tem sido reconhecida eficácia vinculante não apenas à parte dispositiva do julgado, mas também aos próprios fundamentos que embasaram a decisão. Em outras palavras: juízes e tribunais devem acatamento não apenas à conclusão do acórdão, mas igualmente às razões de decidir." (In O Controle de Constitucionalidade no Direito Brasileiro. 2 ed. São Paulo: Saraiva, 2007. p. 184).
} 
Revista Eletrônica de Direito Processual - REDP. Volume 16. Julho a dezembro de 2015

Periódico Semestral da Pós-Graduação Stricto Sensu em Direito Processual da UERJ

Patrono: José Carlos Barbosa Moreira. ISSN 1982-7636. pp. 211-239 http://www.e-publicacoes.uerj.br/index.php/redp/index

interesse público envolvido, que assegura o acesso a este banco de precedentes não apenas aos operadores do direito, mas a todo e qualquer cidadão. Conforme já referido, busca-se uma estabilidade razoável das decisões de nossos Tribunais, especialmente mediante a técnica de formação de precedentes. Trata-se de medida de segurança jurídica imperativa em uma ideia contemporânea de jurisdição, como método de distribuição isonômica de justiça.

Distribuído ao órgão colegiado competente, consoante regimento interno, este procederá ao juízo de admissibilidade do IRDR, averiguando a presença dos pressupostos indispensáveis e cumulativos do art. 976. Caso não admitido, alterado o substrato fático e uma vez preenchidos os requisitos até então inexistentes, qualquer dos legitimados do art. 977 poderá renovar o requerimento de sua instauração (art. 976, §3º).

Não há recurso da decisão de admissibilidade, favorável ou não, uma vez que tal prerrogativa é exclusiva do órgão colegiado competente, necessariamente de segundo grau. Não se nos afigura possível decisão monocrática em relação à admissibilidade deste incidente, diante de ausência de previsão legal a legitimar decisão isolada do relator neste caso. A nosso ver, decisões monocráticas são exceção à regra da colegialidade dos julgamentos nos tribunais, suas hipóteses são excepcionais e restritas, especificados no art. 932 do CPC/2015. Nesse sentido, observe-se que as hipóteses de decisão singular contempladas no art. 932 referem-se restritivamente ao julgamento de recursos e processos de competência originária do Tribunal, mas não preveem a possibilidade de julgamento monocrático de reclamação (art. 988 a 993), de incidente de assunção de competência (arts. 947) ou de incidente de resolução de demandas repetitivas (arts. 976 a 987).

Uma vez admitido o incidente caberá ao relator (i) suspender os processos pendentes individuais e coletivos no estado ou região conforme o caso; (ii) requisitar informações ao juízo no qual tramita o processo que deu origem ao incidente, caso entenda necessário, que as deverá fornecer no prazo de 15 dias (art. 982); e (iii) intimar o Ministério Público para manifestar-se no prazo de 15 dias. Sobressai-se, aí, a força deste incidente, capaz de suspender a tramitação de todos os processos, inclusive coletivos, com igual controvérsia. Relevante constatar que os processos suspensos apresentarão sua complexidade habitual, com pedidos e fundamentos diversos, envolvendo, não raramente, a discussão de mais de uma questão de direito (coincidência parcial com o incidente), além é claro, das questões de fato, sempre únicas a cada demanda. Daí concluir que serão suspensos os processos cuja 
Revista Eletrônica de Direito Processual - REDP. Volume 16. Julho a dezembro de 2015

Periódico Semestral da Pós-Graduação Stricto Sensu em Direito Processual da UERJ

Patrono: José Carlos Barbosa Moreira. ISSN 1982-7636. pp. 211-239

http://www.e-publicacoes.uerj.br/index.php/redp/index

controvérsia objeto do IRDR seja a única questão discutida (coincidência total) assim como aqueles que apresentam outras questões de direito (coincidência parcial).

Os processos pendentes serão suspensos pelo prazo de 01 (um) ano, ressalvados aqueles que envolvem réu preso ou habeas corpus. Superado este prazo cessará a suspensão, salvo decisão fundamentada do relator (art. 980, caput). A limitação do prazo de suspensão dá-se pela razão de que repercutirá - e retardará - o trâmite de todos os processos pendentes. Sob pena de ofensa ao princípio da duração razoável do processo, não se poderá admitir a postergação indefinida ou irrazoável do julgamento, que inclusive deverá ter preferência sobre os demais processos. Ultrapassado o prazo de suspensão e não fundamentada sua postergação, será natural que os julgadores dos processos inicialmente suspensos não se sintam 'estimulados' a decidir, cientes de que seu entendimento pessoal poderá ser revisto quando da fixação da tese no incidente.

Discute-se a cerca da inconstitucionalidade da suspensão compulsória das demandas repetitivas e de seu efeito vinculante, ambos destituídos de prévia autorização constitucional, tal como ocorre em relação às sumulas vinculantes (CF, art. 103-A). Com efeito, a decisão firmada em IRDR apresenta a mesma carga de eficácia das súmulas vinculantes, contudo, sem autorização constitucional. A questão requer maior aprofundamento para a devida análise, escapando aos limites deste breve artigo. Note-se que o fenômeno da suspensão compulsória de casos repetidos e sua eficácia vinculante também ocorre no julgamento de recursos extraordinário e especial repetitivos (art. 1.036, $\S 1^{\circ}$ ), que também não apresentam permissão constitucional, a merecer, por coerência, igual solução na análise de sua compatibilidade com a Constituição.

De qualquer modo, a suspensão apresenta-se como solução eficaz a fim de estender a tese fixada no IRDR uniformemente a todos os processos repetidos, em realização da pretendida isonomia. A suspensão retardará o andamento dos processos em andamento admite-se - contudo, resultará aceleração do seu trâmite até o trânsito em julgado, considerando que a sentença e os acórdãos que se sucederem deverão observar vinculativamente a tese fixada no IRDR (art. 927, III), a menos que ocorra revisão (art. 986), sujeita à eventual modulação de seus efeitos (art. 927, §3). Em reforço desta celeridade postecipada, eventual recurso de apelação em face da sentença que tiver aplicado ou negado aplicação à tese firmada no incidente será julgado por decisão singular do relator (art. 932, IV). Sob outro enfoque, a eficiência do IRDR reside na impossibilidade dos terceiros 
Revista Eletrônica de Direito Processual - REDP. Volume 16. Julho a dezembro de 2015

Periódico Semestral da Pós-Graduação Stricto Sensu em Direito Processual da UERJ

Patrono: José Carlos Barbosa Moreira. ISSN 1982-7636. pp. 211-239 http://www.e-publicacoes.uerj.br/index.php/redp/index

titulares das ações suspensas desvincularem-se da eficácia vinculante do entendimento firmado no IRDR (conhecido como opt out, nas class actions americanas), diferenciandose da sistemática dos processos coletivos, justamente por outorgar tal faculdade aos titulares das ações em curso. A finalidade do IRDR é justamente conferir estabilidade à jurisdição, afastando o inevitável sentimento de injustiça de parte do jurisdicionado que recebe decisão desfavorável em processo com igual controvérsia à demanda de seu amigo, que se sagrou vencedor.

Será natural que durante a suspensão dos processos afetados ocorram pedidos com base em tutela de urgência, os quais serão dirigidos e analisados pelos juízos competentes em que tramitam (art. 982, $\S 2^{\circ}$ ), controláveis via agravo de instrumento (art. 1.015, I). Em regra, não haverá motivo à concessão de tutela de evidência, uma vez que a controvérsia estará justamente aguardando solução uniforme via IRDR, a menos que a evidência esteja unicamente relacionada à questão de fato ou que a questão de direito objeto de evidência não seja a mesma objeto do IRDR. Observa-se que a lei refere apenas tutela de urgência. Entretanto, melhor seria referir o gênero tutela provisória, visto que tutelas de evidência estão legitimadas nas hipóteses referidas.

O Código outorga às partes do processo que deu origem ao incidente, às partes dos processos suspensos em razão do IRDR, bem como ao Ministério Público e à Defensoria Pública (art. 982), a possibilidade de requerer ao Supremo Tribunal Federal ou ao Superior Tribunal de Justiça, conforme o caso, a suspensão em nível nacional de todos os processos individuais e coletivos que versem sobre a questão de direito objeto do incidente (art. 982, $\S \S 3^{\circ}$ e $\left.4^{\circ}\right)$. Uma vez deferida, cessará a suspensão caso não seja interposto o recurso especial e/ou extraordinário em face do acórdão do tribunal local que julgar o IRDR (§5ํ). Trata-se de medida conveniente uma vez identificado que a questão repetitiva transcende às fronteiras regionais e estaduais. Acertadamente, nestes casos, o IRDR sobre controvérsia de interesse nacional terá sua eficiência potencializada e sua eficácia expandida à todo o território nacional, trazendo maior segurança jurídica aos jurisdicionados. Aliás, é de se esperar que tal fenômeno efetivamente ocorra, visto que o pedido de suspensão nacional poderá partir de qualquer dos processos suspensos, sob pena de proliferarem-se IRDR's simultâneos em diferentes tribunais, com fixação de teses antagônicas em diferentes estados da federação.

O art. 983 abre o contraditório para além das partes do processo originário ao viabilizar a manifestação de interessados no julgamento do IRDR, que no prazo conjunto de 15 
Revista Eletrônica de Direito Processual - REDP. Volume 16. Julho a dezembro de 2015

Periódico Semestral da Pós-Graduação Stricto Sensu em Direito Processual da UERJ

Patrono: José Carlos Barbosa Moreira. ISSN 1982-7636. pp. 211-239 http://www.e-publicacoes.uerj.br/index.php/redp/index

(quinze) dias poderão requerer a juntada de documentos e a realização de outras diligências necessárias à elucidação da controvérsia. Tais interessados, aí incluídos os autores de demandas suspensas por força do IRDR, contribuirão para o debate com fatos, informações e fundamentos em um ou outro sentido, poderão requerer diligências, tudo em favor da elucidação da questão de direito, contudo, sem a característica da imparcialidade própria ao julgador, haja vista seu reconhecido interesse na causa (art. 983, caput). Distingue-se, a nosso ver, a participação destes terceiros da figura do amicus curiae. Dúvida não paira a respeito da intimação indispensável do Ministério Público em idêntico prazo (15 dias). Tais prazos deverão ser rigorosamente respeitados de modo que o incidente cumpra seu desiderato no prazo inicial previsto de um ano (art. 980), haja vista a paralização das demandas repetitivas afetadas.

Destaque-se salutar previsão da realização de audiência pública a fim de ouvir-se pessoas "com experiência e conhecimento na matéria" (art. 983, §1ำ), estas com a atributo próprio ao amicus curiae (art. 138), no sentido de contribuir com esclarecimentos e auxiliar o juízo no bom julgamento da questão.

Concluídas tais diligências o relator pedirá dia para julgamento (art. 983, §2º), observando-se, no dia do julgamento, a seguinte ordem dos trabalhos: (i) o relator fará a exposição do incidente; (ii) autor e réu do processo originário poderão sustentar oralmente bem como o representante do Ministério Publico, pelo de prazo de 30 (trinta) minutos cada; (iii) sustentarão os demais interessados, que deverão inscrever-se com no mínimo 02 dias de antecedência e terão 30 (trinta) minutos divididos entre todos, tempo que poderá ser dilatado considerando a quantidade de inscritos (art. 984 caput e $\S 1^{\circ}$ ). Em obediência ao contraditório efetivo e comparticipativo que figura dentre as normas fundamentais do novo diploma $\left(\mathrm{CPC} / 2015\right.$, art. $\left.6^{\circ}\right)$, exige-se que o acórdão do IRDR manifeste-se sobre todos os fundamentos concernentes à tese jurídica objeto de análise (art. 984, $\S 2^{\circ}$ ). Por coerência, como o CPC/2015 impõe tal tarefa na prolação de qualquer decisão judicial (art. 489, $\S 1^{\circ}$, IV), inclusive nas interlocutórias, não haveria razão para excluir-se o aprofundamento do dever de motivação em incidente de tamanha repercussão.

Uma vez julgado, a tese firmada no incidente (art. 985) será aplicada (I) aos processos individuais ou coletivos pendentes de julgamento que versem sobre idêntica questão de direito e que tramitem na área de jurisdição do respectivo tribunal ou região e (II), salvo revisão (art. 986), aos processos futuros, individuais ou coletivos, que versem sobre idêntica 
Revista Eletrônica de Direito Processual - REDP. Volume 16. Julho a dezembro de 2015

Periódico Semestral da Pós-Graduação Stricto Sensu em Direito Processual da UERJ

Patrono: José Carlos Barbosa Moreira. ISSN 1982-7636. pp. 211-239 http://www.e-publicacoes.uerj.br/index.php/redp/index

controvérsia e venham a tramitar na região ou em território de competência do respectivo tribunal. Cuida-se, aqui, da almejada eficácia vinculante do IRDR, para o presente e para o futuro. Tal vinculação ocorrerá, inclusive, em relação aos processos que tramitem ou venham a tramitar nos juizados especiais de cada estado ou região (art. 985), demandas que também deverão ser inicialmente suspensão por ocasião da admissão do IRDR.

Em relação aos casos futuros, deverá o julgador do caso concreto aplicar eventual distinção do julgado em exame em relação à tese firmada no IRDR (arts. 489, § $1^{\circ}$, V e VI, art. $\left.927, \S 1^{\circ}\right)$. Se for este o caso, o precedente não deverá ser aplicado. Do contrário, tratando-se de julgado sobre idêntica questão de direito fixada no precedente, este deverá ser aplicado, de modo que "a fundamentação originária do julgamento do incidente se incorporará automaticamente à própria decisão que o invoca, sem a necessidade de repeti-la ou elaborá-la, razão pela qual não é exigível a observância do art. 489, $1 \S^{\circ}$, IV." 27

Em síntese, o precedente firmado no âmbito do IRDR é dotado de autoridade vinculante (binding autority), produzindo o efeito de vincular os julgados que, em situações idênticas, lhe forem supervenientes. A norma geral estabelecida na fundamentação deste julgado (ratio decidendi) terá a eficácia de vincular decisões posteriores, obrigando os órgãos jurisdicionais a adotarem aquela mesma tese na fundamentação dos julgados sob sua jurisdição, conquanto repouse a controvérsia sobre idêntica questão de direito, em obediência aos princípios da isonomia e segurança jurídica. ${ }^{28}$

O legislador não deixou margem de dúvida a respeito da sua compulsoriedade ("a tese jurídica será aplicada"). Daí porque, caberá aos operadores atentarem com acuidade aos fundamentos determinantes do IRDR e ao suporte fático compreendido na 'moldura' fática do acórdão paradigma. Exemplificativamente, a tese fixada em IRDR poderá ter por pressuposto fático a celebração de determinado tipo de contrato entre o correntista e a instituição bancária, aspecto que deverá ser considerado quando cogitar-se da extensão da mesma tese à julgado que cuide de contrato diverso, ou seja, com suporte fático diverso, em relação ao qual, em princípio, não haverá a necessária vinculação ao precedente.

\footnotetext{
${ }^{27}$ Didier Jr., Fredie; Braga, Paula Sarno Braga; Oliveira, Rafael Alexandria de. Curso de processo civil: teoria da prova, direito probatório, ações probatórias, decisão, precedente, coisa julgada e antecipação dos efeitos da tutela. 10. ${ }^{\text {a }}$ ed. Salvador: Ed. Jus Podivm, 2015, p. 466.

${ }^{28}$ Não se pode desconhecer a dificuldade existente, em alguns casos, em estabelecer qual a fundamentação do precedente deve ser considerada genuinamente como ratio decidente, aquela entendida como ponto central na qual reside a fundamentação extraída da decisão.
} 
Revista Eletrônica de Direito Processual - REDP. Volume 16. Julho a dezembro de 2015

Periódico Semestral da Pós-Graduação Stricto Sensu em Direito Processual da UERJ

Patrono: José Carlos Barbosa Moreira. ISSN 1982-7636. pp. 211-239 http://www.e-publicacoes.uerj.br/index.php/redp/index

Daí interpretar-se com a devida ressalva a regra de que "não observada a tese do incidente caberá reclamação", uma vez que o efeito vinculativo dar-se-á em relação às demandas que apresentem semelhante suporte fático e jurídico do precedente. Deve-se partir da premissa de que direito e fato são inseparáveis em matéria de decisão judicial (aplicação de lei ao caso concreto), mesmo em se tratado de casos repetitivos (art. 928). Não há demanda sem fato. A propósito, conforme já referido, parte da doutrina defende a inconstitucionalidade da eficácia vinculante da tese firmada em IRDR, por ausência de permissão constitucional específica a autorizar tal vinculação, diversamente do que ocorre com as decisões do STF em controle concentrado de constitucionalidade (CF, art. 102, $\left.\S 2^{\circ}\right)$ e súmulas vinculantes emitidas pelo mesmo Tribunal (CF, art. 103, caput).

Prosseguindo, giza-se que o novo Código de Processo Civil fortalece - e muito - a reclamação (arts. 988 a 993), como mecanismo destinado a fazer com que os Tribunais assegurem a observância das suas próprias decisões, bem como das decisões do Supremo em controle concentrado de constitucionalidade, de enunciados de súmula vinculante e de precedentes firmados em julgamento de casos repetitivos ou incidente de assunção de competência (art. 988). Antes restrita à jurisprudência do Supremo Tribunal Federal (CF, art. 102, 1 e 103-A, $\S 3^{\circ}$ ) e do STJ (art. 105, I, f), a reclamação vê-se firmada no CPC/2015 como instituto processual também voltado à garantia da autoridade das decisões dos tribunais locais cuja competência se busca preservar ou autoridade se pretende garantir (art. $988, \S 1^{\circ}$ ). Sua disciplina repete, em maioria, as disposições da Lei 8.038/90, que rege o procedimento da reclamação no âmbito do STF e STJ.

Imbuída de tal propósito, a reclamação será proposta pela parte interessada ou pelo Ministério Público perante o Presidente do Tribunal, necessariamente antes do trânsito em julgado da decisão que lhe desafiou a autoridade (art. 988, $\S 1^{\circ}$ e $\S 5^{\circ}$ ). Cabe observar, que não caberá ação rescisória em face de decisão definitiva que tenha deixado de observar o precedente firmado em IRDR (art. 966), daí por que a parte prejudicada deverá estar atenta a fim de apresentar a reclamação em tempo de evitar a preclusão máxima do julgado dissonante (trânsito em julgado). Recebida a reclamação, se necessário, o relator ordenará a suspensão do processo ou do ato impugnado a fim de evitar dano irreparável (art. 989, II).

Retornando ao procedimento do nosso incidente, o CPC/2015 prevê um importante mecanismo de oxigenação do sistema, ao regrar a possibilidade de revisão da tese firmada no IRDR pelo próprio tribunal que o julgou, de ofício ou a requerimento do Ministério 
Revista Eletrônica de Direito Processual - REDP. Volume 16. Julho a dezembro de 2015

Periódico Semestral da Pós-Graduação Stricto Sensu em Direito Processual da UERJ

Patrono: José Carlos Barbosa Moreira. ISSN 1982-7636. pp. 211-239 http://www.e-publicacoes.uerj.br/index.php/redp/index

Público ou Defensoria Pública, restritivamente (art. 986). Não se trata de recurso ou reclamação, mas de revisão da tese pelo mesmo órgão, definido em regimento, que julgara o incidente. Não haverá limite de tempo quanto à possibilidade de revisão. Também não se exigirá a ocorrência de fato novo a justificar a superação do entendimento anterior. Relevante observar a possibilidade do colegiado modular os efeitos da revisão, tratando de delimitar no tempo a eficácia da sua mudança de entendimento, segundo critérios de segurança jurídica, proporcionalidade e razoabilidade. É certo, porém, que a revisão não terá a força de relativizar a coisa julgada obtida nos processos já transitados em julgado. Dentre as hipóteses taxativas elencadas no art. 966 não há previsão de rescisória baseada na revisão da tese jurídica firmada em IRDR.

Necessário ainda referir o cabimento de recurso especial e/ou extraordinário em relação ao acórdão que julgar o IRDR, respeitadas, é claro, as hipóteses de cabimento constitucionais de cada recurso. O legislador conferiu peculiar atributo a tais recursos diante do interesse público envolvido. Outorgou-lhes, de automático, efeito suspensivo e presumiu repercussão geral à questão constitucional objeto do recurso extraordinário (art. 987, §1º), estimulando sua interposição e acesso aos Tribunais Superiores. Apreciado o mérito, a tese firmada no âmbito do Tribunal Superior, quer mantenha ou reforme o entendimento dos tribunais locais, será aplicada em todo território nacional, a processos individuais e coletivos que versem sobre idêntica questão de direito (art. 987, §2º). Aliás, o interesse recursal estará presente nos legitimados do art. 977, II e III (partes, Ministério Público e Defensoria Pública), em qualquer dos terceiros admitidos à manifestação no incidente (art. 983), extensível às partes de quaisquer processos suspensos por força do incidente, o que nos faz concluir que os Tribunais Superiores seguramente serão convocados, via recurso, a dar a última palavra sobre o incidente.

Ora, se a tese fixada por decisão do STF ou STJ será aplicada em todo o território, é inegável que as partes de qualquer processo suspenso por ocasião do incidente, ainda que fora da área de competência do tribunal estadual, terão interesse e legitimidade recursal. Tal entendimento é corroborado pelo fato de que às partes de demandas repetidas com igual controvérsia é reconhecida legitimidade para requerer a suspensão em nível nacional ao STF ou STJ, conforme o caso, independente dos limites regionais do IRDR (art. 982, ${4^{\circ}}^{\circ}$ ). Reitera-se, todos os caminhos conduzem para que a palavra final sobre a controvérsia repetitiva seja dada pelas Cortes Superiores. 
Revista Eletrônica de Direito Processual - REDP. Volume 16. Julho a dezembro de 2015

Periódico Semestral da Pós-Graduação Stricto Sensu em Direito Processual da UERJ

Patrono: José Carlos Barbosa Moreira. ISSN 1982-7636. pp. 211-239 http://www.e-publicacoes.uerj.br/index.php/redp/index

Por fim, não estará afastado o manejo de embargos declaratórios em face de decisão ou acórdão proferido no âmbito do IRDR, notadamente pela omissão na análise de fundamento suscitado por qualquer interessado (art. 984, $\S 2^{\circ}$ ), sem prejuízo das demais hipóteses de cabimento do referido recurso (art. 1.022).

\section{EFICÁCIA VINCULANTE DO IRDR NO CONTEXTO DA CRESCENTE} VALORIZAÇÃO DOS PRECEDENTES

A força vinculante do precedente gerado a partir do julgamento do mérito do IRDR revela-se na afirmação textual contida no art. 985 de que a tese fixada será aplicada (i) a todos os processos individuais e coletivos que versem sobre idêntica questão de direito, (ii) aos processos no âmbito dos juizados especiais do respectivo Estado ou região; (iii) aos casos futuros que versem sobre idêntica questão de direito; (iv) caso o precedente não seja observado caberá reclamação; (v) terá sua aplicação fiscalizada pela agência reguladora competente caso o precedente firmado diga respeito à prestação de serviço público concedido, permitido ou autorizado; (v) terá aplicação obrigatória salvo revisão do próprio tribunal que julgou o incidente em definitivo. A força vinculante do precedente firmado em IRDR dependerá apenas do julgamento do mérito do mesmo, não obstante em favor ou em desfavor dos interesses do autor da demanda originária.

Registre-se que ao autor da demanda individual ou coletiva suspensa por versar sobre idêntica questão não será outorgado a possibilidade direito de fugir à eficácia vinculante da decisão fixada no IRDR (coisa julgada pro et contra). Trata-se de característica diversa do que se observa no microssistema processual das ações coletivas, no qual é reconhecido ao autor o direito de opt-out, ou seja, de prosseguir com a sua demanda e não sujeitar-se aos efeitos da sentença coletiva caso lhe seja desfavorável (coisa julgada secundum eventum litis). Ataca-se, com isso, uma das principais causas da ineficiência do ordenamento processual no trato de litígios individuais massificados.

Cuida-se de decisiva diferenciação do precedente firmado no âmbito do IRDR em comparação à coisa julgada formada em ação coletiva, outorgando-se àquele capacidade infinitamente superior de racionalizar o sistema e uniformizar a jurisdição, ao negar ao jurisdicionado o direito de não se submeter à tese fixada no incidente. Cuida-se, a nosso ver, 
Revista Eletrônica de Direito Processual - REDP. Volume 16. Julho a dezembro de 2015

Periódico Semestral da Pós-Graduação Stricto Sensu em Direito Processual da UERJ

Patrono: José Carlos Barbosa Moreira. ISSN 1982-7636. pp. 211-239

http://www.e-publicacoes.uerj.br/index.php/redp/index

de saudável e necessária eficiência estabilizadora, em muito superior à sistemática das ações coletivas.

7. O IRDR COMO FERRAMENTA DE RACIONALIDADE E EFICIÊNCIA DA PRESTAÇÃO JURISDICIONAL

A principal contribuição do incidente de resolução de demandas repetitivas ao aprimoramento da prestação da tutela jurisdicional no Brasil será atribuir maior racionalidade e eficiência ao sistema e não, necessariamente, celeridade e efetividade.

Nossa convicção parte da constatação de que a tese fixada no IRDR não afastará a necessidade de que os titulares do direito reconhecido no precedente repetitivo tenham que ajuizar suas ações individuais ou mesmo coletivas a fim de obter o reconhecimento judicial do seu direito, para só então efetivá-lo.

Significa dizer que o julgamento da questão de direito repetitiva via IRDR não importará em uma redução no número de ações futuras em torno daquela mesma questão. Ao inverso, em muitos casos, a solução afirmativa de um direito homogêneo provocará um incremento de ações individuais de parte de todos os seus titulares em busca de seu reconhecimento efetivação judicial. Desnecessário esforço de imaginação para projetar-se um IRDR afirmativo de direito de consumidor, de larga escala, para que milhares de demandas repetitivas desaguem no Judiciário, fortemente estimuladas pela classe dos advogados. Não resta dúvida, entretanto, que esta corrida ao Judiciário será por demais salutar à realização de direitos subjetivos, distribuindo-se farta e igualitária jurisdição. O que não se pode imaginar, no entanto, é que a fixação de tese em IRDR irá reduzir a litigiosidade, irá, isso sim, racionalizar e tornar mais igualitária a distribuição da justiça.

Em reforço, não se pode olvidar que as demandas suspensas por força do IRDR deverão prosseguir com o seu trâmite regular tão logo cessado o seu sobrestamento, mesmo que somente para aplicar a tese firmada no incidente. Em poucas palavras, a fixação da tese via IRDR não afastará a necessidade de que as ações suspensas sejam julgadas até seu trânsito em julgado, com a apresentação de todos os recursos previstos. A preexistência de tese fixada em IRDR trará, contudo, consequências em favor da celeridade do procedimento, podendo ensejar (i) o deferimento de tutela da evidência quando o pedido estiver fundado em tese firmada no precedente; (ii) a dispensa de remessa necessária quando a sentença 
Revista Eletrônica de Direito Processual - REDP. Volume 16. Julho a dezembro de 2015

Periódico Semestral da Pós-Graduação Stricto Sensu em Direito Processual da UERJ

Patrono: José Carlos Barbosa Moreira. ISSN 1982-7636. pp. 211-239

http://www.e-publicacoes.uerj.br/index.php/redp/index

estiver alinhada ao precedente (art. 496, §4 $4^{\circ}$, II); (iii) a improcedência liminar do pedido (art. 332, III), (iv) o julgamento monocrático do mérito de parte do relator (art. 932, IV, 'b’ e V, 'c'); bem como (iv) a dispensa de caução no cumprimento provisório de sentença alinhada ao precedente (art. 521, IV).

Daí concluir que a grande contribuição do IRDR ao sistema processual não guarda relação com o ideal de celeridade do processo e sim com a eficiência e racionalidade do sistema, tornando-o estável e previsível frente a questões de direito repetitivas. Dentre seus principais benefícios, destaque-se ainda o pretendido desestimulo à litigância e esperada redução do número de recursos, diante da previsibilidade gerada pelo precedente. ${ }^{29}$ Nosso otimismo não nos impede de relativizar este último fator (redução do número de recursos), considerando que processo também é cultura, e a práxis estabelecida pelas partes e seus procuradores aponta para o esgotamento das possibilidades de reforma.

Convém constatar a irremediável tendência do novo ordenamento em reduzir em larga medida a esfera de liberdade de atuação reservada aos juízes de primeiro grau. Considerados todos os mecanismos de uniformização elencados no rol do art. 927, resta claro que ao julgador de primeiro grau restará verdadeiramente liberdade de aplicar o direito em campo cada vez mais diminuto e residual de atuação, contido dentre as crescentes balizas impostas pelo ideal de uniformização da prestação jurisdicional.

Não se deve, entretanto, abominar este crescente processo de uniformização, que vem marcado pela necessidade de adequar o processo à realidade dos novos tempos, das demandas de larga escala e da necessidade social e de mercado de obter-se maior segurança e previsibilidade da jurisdição.

Ao juiz de primeiro grau, caberá exercer com acuidade valiosa distinção da demanda sub judice em relação à questão de direito firmada em súmula ou precedente vinculante. Ao juiz singular caberá a tarefa de solucionar as controvérsias de direito não submetidas à previa fixação pelos Tribunais, exercendo sua capacidade, em maior ou menor grau, de renunciar sua convicções pessoais em obediência à qualquer das hipóteses elencadas no art. 927, sob pena reclamação (art. 988). Trata-se de sensível mudança na cultura judiciária, no plano objetivo e subjetivo.

\footnotetext{
${ }^{29}$ Camargo, Luiz Henrique Volpe. O incidente de resolução de demandas repetitivas no projeto de novo CPC: a comparação entre a versão do Senado Federal e a da Câmara dos Deputados. In Novas Tendências do Processo Civil: estudos sobre o projeto do Novo Código de Processo Civil, vol. III. Editora JusPodvim, 2014.
} 
Revista Eletrônica de Direito Processual - REDP. Volume 16. Julho a dezembro de 2015

Periódico Semestral da Pós-Graduação Stricto Sensu em Direito Processual da UERJ

Patrono: José Carlos Barbosa Moreira. ISSN 1982-7636. pp. 211-239 http://www.e-publicacoes.uerj.br/index.php/redp/index

Ao que tudo indica, o tempo reduzirá de forma crescente a esfera de liberdade de atuação dos juízos em primeiro grau, à medida que multiplicarem-se os casos repetitivos, as súmulas e demais precedentes. Faz-se nítida opção de política judicial, em favor da isonomia e da segurança. Projetados os aspectos positivos e negativos deste novo modelo, estamos otimistas em relação ao futuro e em especial à utilidade e eficiência do incidente de resolução de demandas repetitivas.

Parece-nos inegável que este modelo de valorização de precedentes provocará, é certo, um maior acúmulo e centralização de poder nas cortes superiores. No que se refere ao incidente de resolução de demandas repetitivas projetamos sua esmagadora solução final pelas cortes superiores, não apenas em razão da relevância da controvérsia, porque repetitiva, mas também porque estimulada pelo próprio legislador, ao (i) dotar os recursos extraordinário e especiais de automática suspensividade e (ii) presumir a repercussão geral da questão versada no recurso extraordinário (art. 987).

\section{CONCLUSÕES}

A ampliação do acesso à justiça desacompanhado de uma gestão eficiente acarretou prejuízo à qualidade e à tempestividade da jurisdição. Trata-se de fenômeno próprio do Estado Democrático de Direto, decorrente da socialização dos direitos, da incapacidade do Estado em assegurá-los materialmente e da consequente judicialização das pretensões.

Nessa ordem de ideias, o legislador criou e disciplinou o chamado incidente de resolução de demandas repetitivas, nos artigos 976 a 987 do CPC/2015. O IRDR trará solução parcial aos males da ausência de previsibilidade da jurisdição diante de demandas individuais repetitivas. Referido incidente parte da premissa de que, em sede de demandas repetitivas, uniformizar é preciso. Cuida-se de uma das grandes novidades incorporadas ao direito processual brasileiro, instituto de domínio obrigatório pelos operadores do direito.

O precedente firmado no âmbito do IRDR é dotado de autoridade vinculante, produzindo o efeito de vincular os julgados que, em situações idênticas, lhe forem supervenientes. A norma geral estabelecida na fundamentação deste julgado (ratio decidendi) terá a eficácia de obrigar os órgãos jurisdicionais a adotarem aquela mesma tese na fundamentação dos julgados sob sua jurisdição, conquanto repouse a controvérsia sobre idêntica questão de direito. 
Revista Eletrônica de Direito Processual - REDP. Volume 16. Julho a dezembro de 2015

Periódico Semestral da Pós-Graduação Stricto Sensu em Direito Processual da UERJ

Patrono: José Carlos Barbosa Moreira. ISSN 1982-7636. pp. 211-239 http://www.e-publicacoes.uerj.br/index.php/redp/index

O IRDR estabelece verdadeiro rompimento com o paradigma individualista do CPC/1973, guardando obediência aos preceitos constitucionais da duração razoável do processo, da segurança jurídica e da isonomia processual, a partir de um tratamento uniforme na resolução de questões de direito e na distribuição da justiça.

A tese fixada no IRDR não afastará a necessidade de que os titulares do direito reconhecido no precedente repetitivo tenham que ajuizar suas ações individuais a fim de obter o reconhecimento do seu direito, para só então efetivá-lo. Daí concluir que a grande contribuição do IRDR ao sistema processual não guarda relação com o ideal de celeridade do processo e sim com a eficiência e racionalidade do sistema, tornando-o estável e previsível frente a questões de direito repetitivas.

Afigura-se inegável, por último, que este modelo de valorização de precedentes provocará, é certo, um maior acúmulo e centralização de poder nos Tribunais Superiores. No que se refere ao incidente de resolução de demandas repetitivas projetamos sua esmagadora solução final pelo Superior Tribunal de Justiça e pelo Supremo Tribunal Federal, resguardada as hipóteses constitucionais de competência de cada tribunal.

\section{REFERÊNCIAS BIBLIOGRÁFICAS:}

ABBoud, Georges. Cavalcanti, Marcos de Araújo. Inconstitucionalidades do incidente e resolução de demandas repetitivas (IRDR) e os riscos ao sistema decisório. Revista de Processo, vol. 240/2015, p. 221-242, fev/2015.

AMARAL, Guilherme Rizzo. Efetividade, segurança, massificação e a proposta de um incidente de coletivização. in Processo Coletivo e outros temas de direito processual: homenagem 50 anos de docência do professor José Maria Rosa Tesheiner e 30 anos de docência do Professor Sérgio Gilberto Porto. Livraria do Advogado. Porto Alegre, 2012, p. 237-259.

ATAÍDE JR. Jaldemiro Rodrigues de. As demandas de massa e o projeto de novo código de processo civil. in Novas Tendências do Processo Civil: estudos sobre o projeto do Novo Código de Processo Civil, vol. III. Editora JusPodvim, 2014.

BARroso, Luís Roberto. in O Controle de Constitucionalidade no Direito Brasileiro. 2 ed. São Paulo: Saraiva, 2007. p. 184. 
Revista Eletrônica de Direito Processual - REDP. Volume 16. Julho a dezembro de 2015

Periódico Semestral da Pós-Graduação Stricto Sensu em Direito Processual da UERJ

Patrono: José Carlos Barbosa Moreira. ISSN 1982-7636. pp. 211-239 http://www.e-publicacoes.uerj.br/index.php/redp/index

BuENo, Cassio Scarpinella. Visão geral do(s) projeto(s) de novo código de processo civil. Revista de processo, vol. 235/2014, p. 353-378, set/2014.

CABral, Antônio do Passo. A escolha da causa-piloto nos incidentes de resolução de processos repetitivos. Revista de Processo, vol. 231/2014, p. 201-223, mai/2014.

CAMARGO, Luiz Henrique Volpe. O incidente de resolução de demandas repetitivas no projeto de novo CPC: a comparação entre a versão do Senado Federal e a da Câmara dos Deputados. In Novas Tendências do Processo Civil: estudos sobre o projeto do Novo Código de Processo Civil, vol. III. Editora JusPodvim, 2014.

CAMBI, Eduardo. Estratégia nacional de prevenção e de redução de litígios. Revista de Processo, vol. 237/2014, p. 435, nov/2014.

CAvalcanti, Marcos de Araújo. Mecanismos de resolução de demandas repetitivas no direito estrangeiro: um estudo sobre o procedimento-modelo alemão e as ordens de litígios em grupo inglesas. Revista de processo. Ano 39, vol. 238, dez/2014, p. 335-377.

Cavalcanti, Marcos de Araújo. $O$ incidente de resolução de demandas repetitivas e as ações coletivas. Salvador: JusPodivm, 2015.

DIDIER JR., Fredie. Paula Sarno Braga e Rafael Alexandria de Oliveira. Curso de Direito Processual Civil. 10. Ed. Salvador: Ed. Jus Podvim, 2015, vol. 2.

Dworking, Ronald. Levando os direitos à sério. Trad. Nelson Boeira. 3 ed. São Paulo: Martins Fontes, 2010, p. 172-173.

FLACH, Daisson. Processo e realização constitucional: a construção do "devido processo". In Amaral, Rizzo Guilherme; Carpena, Marcio Louzada (coord.). Visões críticas do processo civil brasileiro. Porto Alegre: Livraria do Advogado, 2005.

Fredie Didier Jr., Paula Sarno Braga e Rafael Alexandria de Oliveira. Curso de processo civil: teoria da prova, direito probatório, ações probatórias, decisão, precedente, coisa julgada e antecipação dos efeitos da tutela. 10. Ed. Salvador: Ed. Jus Podivm, 2015, p. 466. GAIO JR., Antônio Pereira. Incidente de resolução de demandas repetitivas no projeto do novo CPC: breves apontamentos. Revista de processo 2011, Repro, ano 36, vol. 199, set/2011, p. 249-256.

JoBIM, Marco Félix. O direito fundamental à duração razoável do processo e a responsabilidade civil do Estado em decorrência da intempestividade processual. 2. ed. rev. e ampl. Porto Alegre: Livraria do Advogado Editora, 2012. 
Revista Eletrônica de Direito Processual - REDP. Volume 16. Julho a dezembro de 2015

Periódico Semestral da Pós-Graduação Stricto Sensu em Direito Processual da UERJ

Patrono: José Carlos Barbosa Moreira. ISSN 1982-7636. pp. 211-239 http://www.e-publicacoes.uerj.br/index.php/redp/index

LARENZ, Karl. Metodologia da ciência do direito. $2^{\mathrm{a}}$ ed. Tradução José de Souza e Brito e José Antônio Veloso. Lisboa: Fundação Calouste Gulbekian, 1969, p. 502.

Mandelli, Alexandre Grandi. O Incidente de Resolução de Demandas Repetitivas. Revista

Síntese de Direito Civil e Processual Civil, vol. 13, n. 93, jan/fev 2015, p. 09-29.

Marinoni, Luiz Guilherme. Arenhart, Sérgio Cruz, Mitidiero, Daniel. Novo curso de processo civil: teoria do processo civil, vol. 1. Editora Revista dos Tribunais, 2015, p. 147. MarINONI, Luiz Guilherme. Precedentes obrigatórios. 2a ed. São Paulo: Ed. RT, 2011, p. 65.

OliveirA, Guilherme Peres de. Incidente de resolução de demandas repetitivas - Uma proposta de interpretação de seu procedimento. Novas In Novas Tendências do Processo Civil: estudos sobre o projeto do Novo Código de Processo Civil, vol. II, Editora JusPodvim, 2014.

PorTO, Sérgio Gilberto. USTÁRROZ, Daniel. Lições de Direitos Fundamentais no Processo Civil. Porto Alegre: Livraria do Advogado Editora, 2009. p. 41

Rossi, Júlio César. O precedente à brasileira: súmula vinculante e o incidente de resolução de demandas repetitivas. Revista de Processo, ano 37, vol. 208, junho/2002, p. 203-240.

TesheINeR, José Maria Rosa. Celeridade ou tempestividade processuais? Processos Coletivos. Revista Eletrônica- Porto Alegre, ano 2015, v. 6, n. 3, julho a setembro.

Disponível em http://www.processoscoletivos.net/ ppoletiv/ponto-e-contraponto/726celeridade-ou-tempestividade-processuaism.

Theodoro Júnior, Humberto. Nunes, Dierle. Bahia, Alexandre Melo Franco. Pedron, Flávia Quinaud. Novo CPC: fundamentos e sistematização. 2a ed. Rio de Janeiro: Forense, 2015.

VALCANOVER, Fabiano Haselof. O princípio do acesso à justiça após a Emenda Constitucional no 45/2004. Revista Páginas de Direito, Porto Alegre, ano 14, no 1104, 30 de janeiro de 2014. Disponível em: http://www.tex.pro.br/home/artigos/259-artigos-jan2014/6386-o-principio-do-acesso-a-justica-apos-a-emenda-constitucional-n-45-2004.

VIAFORE, Daniele. As semelhanças e as diferenças entre o procedimento-modelo alemão musterverfahren e a proposta de um 'incidente de resolução de demandas repetitivas' no PL 8.046/2010. Revista de Processo, ano 38, vol. 217, mar/2013, p. 257-308. 
Revista Eletrônica de Direito Processual - REDP. Volume 16. Julho a dezembro de 2015

Periódico Semestral da Pós-Graduação Stricto Sensu em Direito Processual da UERJ

Patrono: José Carlos Barbosa Moreira. ISSN 1982-7636. pp. 211-239 http://www.e-publicacoes.uerj.br/index.php/redp/index

ZANFERDINI, Flávia de Almeida Montingelli. GoMEs, Alexandre Gir. Tratamento coletivo adequado das demandas individuais repetitivas pelo juízo de primeiro grau. Revista de Processo. Ano 39, vol. 234, agosto, 2014. Revista dos Tribunais. p. 181-207.

Zavascki, Teori Albino. Processo Coletivo: Tutela de Direitos Coletivos e Tutela Coletiva de Direitos. 2. ed. São Paulo: Revista dos Tribunais, 2007. p. 57. 